\title{
African Reading of Psalm 24:3-6: The Implications for the Enforcement of Morality among Christians in Africa.
}

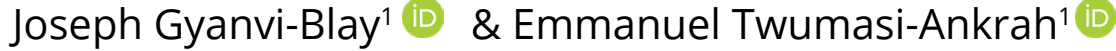 \\ 1 Department of Theology, Christian Service University College, Kumasi-Ghana.
}

\begin{abstract}
This paper deals with the African reading of Psalm 24:3-6: The implications for the enforcement of morality among Christians in Africa. The book of Psalms is subdivided into five books comparable to the Pentateuch. Psalm 24 falls into the first book which is used as a liturgy of entrance into the Israelite temple. In Psalm 24:3-6 a worshipper asks for entry requirements to be met which are clean hands and pure hearts, not lifting up the soul to what is false, and not swearing deceitfully. The methodology used is the African perspective of readers' response. Pastors and Christian leaders must lead the people with integrity befitting the sacredness of the hill of the Lord. Christians are the temple of God and are expected to observe ritual purity everywhere every time in order to receive blessings from God, (Onyame).
\end{abstract}

Correspondence:

Joseph Gyanvi-Blay

Email: jgblay@csuc.edu.gh

Manuscript

Received 1st February, 2021

Accepted 8th March, 2021,

Published online 15th March, 2021.

Keywords: Morality, Shrine, clean hands, pure hearts, ritual purity.

(C) 2021 The Author. Published and Maintained by Noyam Publishers.

This is an open access article under the CCBY license (http://creativecommons.org/licenses/by/4.0/).

\section{INTRODUCTION}

The name "Book of Psalms" originated from the Greek title Psalmoi with a subtitle Biblos psalmon which means stringed instrument or a collection of songs which can also be equated to mizmôr in Hebrew which also means hymns. ${ }^{1}$ According to Sabourin, ${ }^{2}$ the book of psalms comprising 150 chapters is subdivided into five books (1-41, 42-72, 73-89, 90-106, 107-150). These five divisions of the book of psalms are referred to as the Psalter, where Psalm 24 is also found. Mowinckel $^{3}$ is also of the opinion that the title of the book of Psalms is derived from the Hebrew word těhillim, meaning cultic songs of praise. This means psalms were used for sacred activities of the Israelite cult of Yahweh in the Second Temple. ${ }^{4}$ In performing the sacred activities, the Psalter was used as a hymnbook in the cult of the Second Temple which is the Israelite post-exilic temple. Kselman \& Barré also see the Psalter as the songbook meant to be used in the temple. ${ }^{5}$ This temple (hěkāl, Hebrew word for both temple and palace) was Yahweh's palace where he resided to rule the earth just as human kings do from their palaces. ${ }^{6}$

The various activities involved in the Israelite cult are summarized as the "visible and audible expressions of the relation between the congregation and the deity." "The people involved in a relationship are the people of Israel referred to as the congregation, while their deity is Yahweh, the God of Israel. The visible and audible expressions are seen in the worship service conducted in the temple. ${ }^{8}$ According to Mowinckel, "religion appears in three main aspects, as a cult, as a myth and as an ethos. Or, in other terms, as worship, as doctrine, and as behaviour (morals)."

From Mowinckel's research, it can be said that it was for the people of Israel expressing their sentiments during worship that the psalms were composed as songs, poems and prayers to be used in the temple. ${ }^{10}$ In the temple, psalms

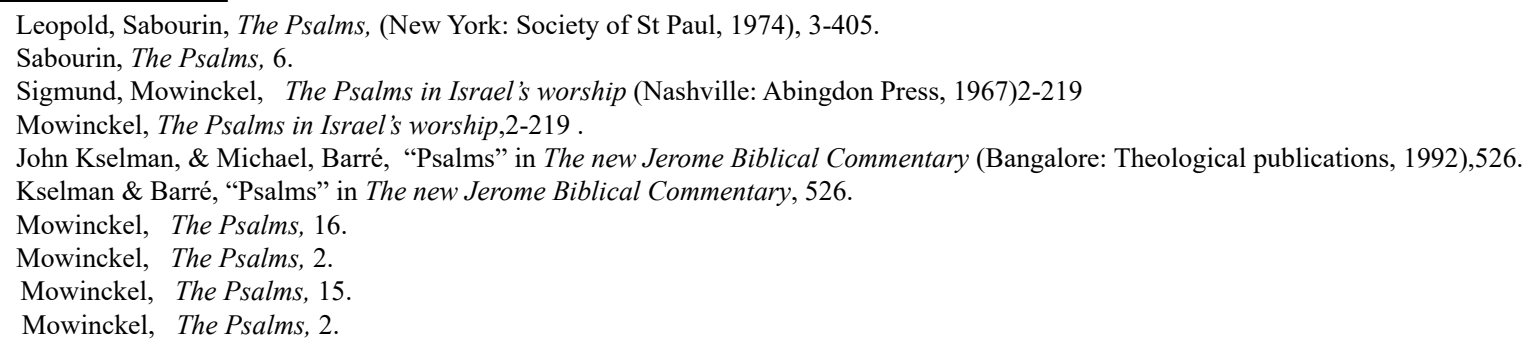


were used as music performed by Levitical singers during major activities of the cult such as solemn festivals and daily sacrifices in the temple.

Hayes asserts that the division of the book of psalms into five portions is an editing devise used by the redactors to make the book similar in pattern to the tôrăh or the Pentateuch. ${ }^{11}$ Hayes' assertion above relating the book of Psalms with the tôrāh is derived from the Midrash which states that "as Moses gave the five books of the law to Israel, so David gave five books of Psalms to Israel."12 Midrash, according to the Concise Dictionary of Christian Theology, is the Jewish rabbinic commentary on the Hebrew Bible and the quotation made by Hayes from the Midrash is from the commentary on Psalm $1 .^{13}$

Apart from topics such as the literary types in the book of Psalms, African religious beliefs concerning God, the use of sacred space in enforcing morality etc., how Yahweh became the Israelite God will also be discussed in this study. For the sake of the discussion in this study, the God of Israel or God, according to ancient Israelite belief will be referred to as Yahweh whiles that of Africa will be the Supreme Being (a general African term) or Onyame for Akans of Ghana and Olódùmarè for the people of Yoruba in Nigeria. As Ghanaian researchers, that of Akan will be used in due course. In the course of the discussions, a few teachings from the New Testament will be used since that could have useful implications for African Christians. All the biblical texts are quoted from New Revised Standard Version.

The work discusses how Yahweh became an Israelite deity, the literary types and the content pericope, explains the African Traditional religious belief in the supernatural being and its implications on the enforcement of Morality. It goes on further to discuss how an oath is used in establishing the truth, the use of the sacred space in the enforcement of morality, and also discusses the methodology of the African religious reading which is a readers-response.The work also discusses how the religious beliefs play on the text under review and the implications of the text for the enforcement of morality among African Christians and concludes that the African Christian is expected to observe ritual purity due to the feeling of awe expressed towards the supernatural beings.

\section{Yahweh as the Israelite deity}

The Hebrew Bible (The Old Testament) refers to the Israelite God by a number of names, titles and epithets. ${ }^{14}$ The name of the Israelite God was furthermore attached to a place, and this place was reserved for worship..$^{15}$ This assertion is supported later by the facts that, first, in Deborah's song in Judges 5:4,5 Deborah speaks of Yahweh coming out from Seir which is a mountainous area called Sinai; second, Amos speaks of Yahweh roaring from Zion; and thirdly, Elijah goes to Horeb, the mount of God to meet with him. ${ }^{16}$ Yahweh made a covenant with his people who pledged themselves to a monotheistic faith. ${ }^{17}$

Modriaan discovers, from extra-biblical information, that the name Yahweh for the Israelite God was associated with a group of nomads, Shasu in the Sinai Peninsula. Yahweh was even discovered from this group to have been established and located in Sinai and revealed himself in thunder, smoke, fire, and earthquake and was brought to Palestine between the late bronze era. From the discussions above, Yahweh is the Israelite God addressed in various ways through the book of Psalms. The next section would further discuss the literary styles or forms found in the book of Psalms.

\section{Literary types (Genre) of the book of Psalms}

The classification of the book of Psalms into various literary types is based on its form, structure and content. ${ }^{18}$ This has been made possible due to the form-critical studies conducted by Herman Gunkel. According to Gunkel, there are five main literary types which are:
1. Hymns
2. Communal Laments
3. Thanksgiving songs of the individual
4. Spiritual Laments of the Individual
5. Mixed types and further developments. ${ }^{19}$

\footnotetext{
11 John Hayes “The songs of Israel: Psalm and Lamentation” in The Hebrew Bible today: An Introduction to critical issues (Louiville, Kentucky: Westminster John Knox Press, eds Steven L. Mckenzie \& M. Patrick Graham, 1998), 154.

12 Hayes "The songs of Israel: Psalm and Lamentation",154.

13 Millard Erickson, The Concise Dictionary of Christian Theology, (Wheaton, Illinois: Crossway books, Good news Publishers, 2001 ), 126.

14 Marlene E Mondriaan, The Rise of Yahwism: role of marginalized groups, (Unpublished doctoral thesis, Department of the Old Testament Studies. University of Pretoria. 2010), 230.

15 Mondriaan, The rise of Yahwism, 230.

16 William. O. E. Oesterley \& Theodore. H. Robinson, Hebrew religion: Its origin and development. (London: S.P.C.K., 1961),154..

7 Mondriaan, The rise of Yahwism, 311.

18 Hayes "The songs of Israel: Psalm and Lamentation", 154.

19 Herman, Gunkel, The Psalms: A form-critical Introduction, trans. Thomas M. Honer, (Philadelphia: Fortress Press, 1969),30-39.
} 
According to Gunkel, the first literary type is referred to as hymns which are derived from the Hebrew word, těhillāh which means to sing a hymn. ${ }^{20}$ Gunkel also observes a basic form of a hymn to contain the word Halleluyah which either begins or concludes it. The main body also entails the attributes and the deeds of God which elicits the praise. These attributes are expressed in a relative clause, beginning with "who" depicted in Psalm 103:3-5"who forgives all your iniquity, who heals all your diseases, who redeems your life from the Pit..." 21

The second category of the literary type is the lament which is an appeal or petition of Yahweh for assistance for the community (Communal lament). ${ }^{22}$ In Communal Lament (C.L), "the woeful plight of the people is depicted; it is bewailed and lamented with copious tears. These are the vengeful cries of a tormented people." In other words, the type of lament is that of the nation and their plight, expressed in the context of much crying by the whole nation whenever hey are tormented by a certain crisis.

The third literary type is the thanksgiving offering from the Hebrew word tôdāh. According to Gunkel, a thanksgiving offering is presented to Yahweh when an individual, having been saved out of distress such as shipwreck, imprisonment and illnesses, shows gratitude out of the cheerful heart by thanksgiving offering. ${ }^{23}$

The spiritual lament of the individual is the fourth literary type. This category is observed by Gunkel to be the "imperishable treasure in the Psalter" and also postulates that "pure and authentic religion is to be found only where tremendous struggles have been experienced." ${ }^{24}$ This means that heartfelt and genuine piety is seen among people who are going through suffering.

Hayes again points out another category of a literary type that is designated for the Israelite king, otherwise known as the royal Psalms. ${ }^{25}$ Gunkel, on this category, posits that the ancient people including Israel held the king to be in a close relationship with their deity and so received songs sung for him. ${ }^{26}$ The royal Psalm has the text focusing either on the king or the speaker. In this category either the king is giving thanks to Yahweh or petitioning Yahweh on behalf of the nation. ${ }^{27}$ Sabourin asserts that the royal Psalm is also composed to honour the king due to his role as Yahweh's representative and the most important personality and also contains a prayer for him. ${ }^{28}$ In addition to the five major literary types classified by Gunkel's form-critical studies discussed above, there are also minor literary types that are going to be discussed. ${ }^{29}$ Some of the minor categories are the Pilgrim Psalms, Victory Psalm, Communal songs of thanksgiving, Liturgies and Dialogues, Wisdom Poetry and Mixed Poems. ${ }^{30}$ The Pilgrim Psalms are songs sung in preparation towards an occasion of pilgrimage which is a journey to a sacred or solemn assembly scheduled at a specified place. ${ }^{31}$ The victory Psalm is a song sung by military men who have won a victory in a war. There is also the communal thanksgiving song which is used for special services in the temple. Wisdom poetry is characterized by its instructional expressions similar to that of the wisdom literature (Proverbs, Job and Ecclesiastes) and mixed poems which display a combination of a variety of Psalms like laments, thanksgiving and hymns.

Even though the Psalter is widely used as part of the liturgy (A rite prescribed for public service by MeriamWebster collegiate Dictionary) of the Israelite cult, some of them are specifically noted for their special use and as such have a specialized literary style. This group is referred to by scholars like Kselman \& Barré and Sabourin as liturgical Psalms. Psalms 15 and 24 are the main examples to be considered but 134 is sometimes mentioned. This group has been noted to be a rite or ritual of the entrance to the temple where the worshippers are required to seek admission into the temple (Pss 15:1; 24:3). ${ }^{32}$ Having dealt with the various literary styles, the pericope or the text itself will be discussed.

\footnotetext{
20 Gunkel, The Psalms: A form-critical Introduction, 30-39.

Gunkel, The Psalms: A form-critical Introduction, 30-39.

Hayes "The songs of Israel: Psalm and Lamentation," 157.

Gunkel, The Psalms: A form-critical Introduction, 17

Gunkel, The Psalms: A form-critical Introduction, 17.

Hayes "The songs of Israel: Psalm and Lamentation," 157.

Gunkel, The Psalms: A form-critical Introduction, 23.

Kselman, \& Barré, "Psalms" 525.

Sabourin, The Psalms 335.

Gunkel, The Psalms: A form-critical Introduction, 23.

Hayes "The songs of Israel: Psalm and Lamentation," 160.

Hayes "The songs of Israel: Psalm and Lamentation," 160.

Kselman \& Barré, "Psalms" 526.
} 


\section{Psalm 24-Pericope}

The earth is the LORD's and all that is in it,

The world, and those who live in it;

For he has founded it on the seas,

And established it on the rivers.

\section{2}

Who shall ascend the hill of the LORD?

And who shall stand in his holy place?

Those who have clean hands and pure hearts,

Who do not lift up their souls to what is false,

And do not swear deceitfully.

They will receive blessing from the LORD,

And vindication from the God of their salvation.

Such is the company of those who seek him,

Who seek the face of the God of Jacob?

3

Lift up your heads, $O$ gates!

And be lifted up, $\mathrm{O}$ ancient doors!

That the King of glory may come in.

Who is the King of glory?

The LORD, strong and mighty,

The LORD, mighty in battle.

Lift up your heads, O gates!

And be lifted up, $\mathrm{O}$ ancient doors!

That the King of glory may come in.

Who is this King of glory?

The LORD of hosts,

$\mathrm{He}$ is the King of glory.

Psalm 24 contains a hymn of praise to Yahweh who has been the victorious creator of the earth and also serves as an entrance liturgy. ${ }^{33}$ Dahood believes the psalm was composed as a liturgy to be used for the procession of the Ark of the Covenant $^{34}$ (which is a symbol of Yahweh, the divine king, who had victory over the chaotic waters during the creation), as well as in the Israelite temple. ${ }^{35}$

Mowinckel divides Psalm 24, the pericope, into three stanzas according to the occasions involved in the ritual. ${ }^{36}$ The first stanza is sung on the occasion of the procession on the way to the temple (1-2), the second stanza just before the gate (3-6) and finally the third through the gate into the temple (7-10). In this case, the procession will be led by those Levitical priests who will be carrying the ark and other priests that will be conducting the service followed by the worshippers. When the ark is getting into the temple through the gates, those Levitical priests will be singing the third part (7-10). As the ark gets into the temple the rest of the worshippers will be at the gate to inquire from the priests who are in the temple of the moral qualifications necessary for admission into the temple as indicated earlier. The priests will then respond to the inquiries by enumerating four moral qualifications for any worshipper who wants to be granted admission into the temple. Having spelt out the moral qualifications, the priest concludes with a pronouncement of blessing. In this vein, in order for African reading of the text to be successful, there is the need to deal with the African Theology or beliefs concerning God and how his worship enforces morality among African traditional worshippers or believers.

\section{African Traditional Religious Beliefs in God and other Spiritual Beings: Implications for the Enforcement of Morality.} Africans are not aliens to the worship of the monotheistic or one God, the Supreme Being who is called by various

\footnotetext{
33 Kselman \& Barré, "Psalms" 530

34 Mitchell, Dahood, Psalm 1-50: Introduction, translation and Notes (London: Yale University Press, 2003$), 150$.

35 John Day Psalms (New York: T\&T Clark International, 1999)60.

36 Mowinckel, The Psalms, 6.
} 
names in Africa. ${ }^{37}$ For example, Onyame is used by the Akans of Ghana and Olódùmarè, by the people of Yoruba of Nigeria. From Idowu's research, Africans believe that "God is one, not many; and that to the one God belongs the earth and all its fullness." 38 The name Olódùmarè, describes the Supreme Being as one who possesses a unique crown, in addition to a royal scepter. ${ }^{39}$ It is further posited by Idowu that Olódùmarè is believed by the people of Yoruba, to be the "head and Overlord of all in heaven and on earth; indisputably, absolutely, unique and beyond comparison in majesty and fullness of attributes." The name Olódùmarè also carries an idea of a personality who is capable of entering into a covenant with humanity and he is also noted to be incomparable, excellent, stable, unchanging, constant and reliable.

Again, in Africa, the Supreme Being is conceived of as a supreme king who has appointed many servants or divinities appointed to minister in various departments in the theocratic governance of the world. ${ }^{40}$ Mbiti is also of the opinion that divinities, known as Abosom (for plural and Jbosom for singular in Akan), are created by the Supreme Being, Onyame, associated with him and manifest his presence. ${ }^{41}$ Contrary to Mbiti's opinion on divinities being created by the Supreme Being, Idowu posits, from his research into the cosmology of the people of Yoruba, that divinities emanate from the Supreme Being and are his children and not created. ${ }^{42}$ Ancestors (Nsamanfos in Akan) another group of ministers of the Supreme Being, tend to serve as the intermediaries between the Supreme Being and the living. Ikechukwu defines ancestors, called Ndiichie or Ndibunze, in Igbo, as those men and women who led good and exemplary lives when they were in the physical world, and are believed to continue their existence in the spiritual world. ${ }^{43}$

In another African belief, the Supreme Being has revealed himself as all-knowing and all-powerful in many ways, and in view of that, human beings have also responded in many ways. Therefore the response of human beings to the Supreme Being has been demonstrated in Africa as worship. ${ }^{44}$ According to Mbiti, worship is a means of renewing contact between people and God or between people and the invisible world. ${ }^{45}$ Due to the self-revelation of the Supreme Being in human lives and the corresponding response in worship, such interaction between the Supreme Being and human beings create a relationship that is referred to as religion. ${ }^{46}$

Idowu remarks that personal conditions qualify one for worship. Such conditions pertain to moral and ritual cleanliness. Idowu clearly explains this by saying that "the greatest obstacle to efficacious worship is the impurity of the heart. Thus moral and ritual cleanliness have from time immemorial been accepted as a prerequisite of Yoruba worship". ${ }^{47}$ This means that any worshipper must abstain from all misconducts or observe all prohibitions in order to be morally pure to qualify for worship at any shrine or sacred space. If one defiles himself or herself prior to such worship, that person must be purified through sacrifice.

Ikenga-Metuh's research on the Igbo speaking people of Nigeria reveals that the Igbo word Nso literally means avoidance or prohibition. ${ }^{48}$ In other words what one must avoid or be prohibited from doing. Ikenga-Metuh opines that NsQ also stands for 'holy' which is associated with the lesser gods and the ancestors (the supernatural beings), shrines and the priests and for anyone to assume such status of holiness, one must avoid coming into contact with those prohibitions. ${ }^{49}$ This means a breach of any of such prohibitions is considered to be an abomination or a taboo called alu in Igbo. Some examples of prohibitions in Igbo traditional morality, according to Ikenga-Metuh's research, include incest, murder, suicide by hanging, fighting a masquerade, bestiality (having sex with an animal), stealing yams and sheep, willful abortion, pregnancy within a year of husband's death and so on. It can be deduced that anybody who commits any of the above abominations or breaks a taboo becomes polluted and as such, not qualified to approach anything that has to do with the 'holy', like coming to the shrine and also calling upon or invoking any lesser god or ancestor.

Ushe postulates that Africans believe that the Supreme Being judges human beings right away on the earth. In his judgments, the Supreme Being rewards good people and punishes wrongdoers. ${ }^{50}$ This judgment does not wait till

\footnotetext{
37 Ushe Mike Ushe, "God, Divinities and Ancestors in African Traditional Religious thought” Igwebuike: An African Journal of Arts and Humanities 3:4, June (2017), 155.

38 Bolaji E. Idowu, Olódùmarè: God in Yoruba belief(London: Longmans Green and Co. Ltd, 1966), 31.

39 Idowu, Olódùmarè: God in Yoruba belief, 31.

40 Ushe, "God, Divinities and Ancestors in African Traditional Religious thought," 155.

41 John S. Mbiti, African Religions and Philosophy, (Garden City, New York: Anchor Books Doubleday \& Company, Inc., 1970$)$, 98.

42 Idowu, Olódùmarè: Olódùmarè: God in Yoruba belief, 66.

43 Nwafor Matthew Ikechukwu, "The living-dead (ancestors) among the Igbo-African people: An interpretation of Catholic Sainthood" International Journal of Sociology and Anthropology (2017);37.

44 Ushe, "God, Divinities and Ancestors in African Traditional Religious thought", 155

45 John S. Mbiti, Introduction to African Religion.(Nairobi: Heinemann Educational Publisher, 1991), 60.

46 Ushe, "God, Divinities and Ancestors in African Traditional Religious thought", 155.

47 Idowu, Olódùmarè: God in Yoruba belief, 108.

48 Emefie Ikenga-Metuh "Ritual Dirt and Purification Rites among the Igbo" Journal of Religion in Africa, 15:1 (1985), 4.

49 Ikenga-Metuh "Ritual Dirt and Purification Rites among the Igbo" 4.

50 Ushe, "God, Divinities and Ancestors in African Traditional Religious thought”, 164.
} 
one dies and so the idea of people being punished or rewarded after death is not popular in Africa. ${ }^{51}$ The belief in the judgments of the Supreme Being is further explained by the fact that he is believed by Africans as an angry one "who detests evil of all kinds." This anger of God is "conceptualized in the lightning and thunder that struck trees, buildings animals and human beings.Ethnic groups in West Africa especially the Igbo ethnic group from Nigeria, believe that the divine being, Amadioha is the delegated minister who expresses the anger of the Supreme Being with thunder on offenders. ${ }^{52}$ Among the Akan ethnic group of Ghana, it is also believed that the Supreme Being himself, who is addressed as Onyame, uses his axe (Onyame Akuma, God's axe) to strike wrongdoers. ${ }^{53}$ According to Ushe, some groups of people in Africa believe that the sun, moon and skies serve as eyes that see the most hidden secrets. This means everyone under the jurisdiction of the sun, moon and the skies is being watched in all ramifications of life both in motives and deeds.

Kudadjie also postulates that the people of the Ga-Adamgbe traditional society of Ghana believe in the Supreme Being who is known to them as Nyinmo or Nyonmo and the various divinities who are invoked or called upon by the people to enforce morality. ${ }^{54}$ Furthermore, the people believe that the people who kept the moral code are blessed and protected by the Supreme Being and the divinities while those who indulge in wrongdoing are punished.

A case was reported in Teshie, a suburb of Accra in Ghana, where a thief, after stealing crops in someone's farm could not move for three days and was found weeding the farm. It took the owner of the farm to come to the farm to remove a spell on the thief before he could move. ${ }^{55}$ In another instance, the thief had to go to a shrine to confess what he had done before he was made free. Kudadjie again explains that curses are invoked on people who engage in illicit sexual affairs and the consequence of this curse is the inability of the culprits to separate after the act and even if they later separate the man becomes impotent.

According to Nwosu, Ala is a divinity responsible for the land or regarded by the Igbo tribe of Nigeria as the earth goddess of fertility. ${ }^{56}$ Such divinity is believed to be the custodian of public morality in partnership with the ancestors. ${ }^{57}$ Nwosu further explains that offenses such as sexual intercourse outside a human residence or in the bush, stealing food crops from farms, incest, and infidelity on the part of wives, etc., are considered by the Igbo as offenses against Ala which attract sudden death and various diseases if ritual purification by sacrifice is not done.

\section{The use of an oath in establishing the truth}

The researchers believe that swearing an oath is a way of either enforcing truth-telling and eschewing lies in African society or ensuring one's commitment to being truthful to a course of action. Agyekum uses Elmar Klinger's definition of the act of swearing an oath which says that:

An oath is a promise made before some institutional authority. In taking an oath, a person not only assumes an obligation but also becomes liable to prosecution; the state and society have an interest in his act. Oaths serve as objective guarantees of what is promised. Swearing to tell the truth, one guarantees that what one says is true. Oaths are self-endorsing. It is the best verification of the truth. ${ }^{58}$

Agyekum further explains that the oath-taker sometimes invites the society to bear witness to the oath to guarantee that what is said is true. ${ }^{59}$ In this case, the entire society demands sincerity from the oath-taker. According to Agyekum, an oath in Akan traditional belief, is also an act of recalling mournful events, dark secrets, weaknesses and shortcomings that must not be brought back hence it becomes a verbal taboo for such words to be uttered. It is also believed, among the Akans, that there is a power behind the oath which makes it capable of recurrence hence must not be repeated. Agyekum is also of the opinion that anybody who swears an oath in a wrong context (swears when there is no need for that) or in falsehood is said to use an oath inappropriately hence liable for assassination either by the people or afflicted by the divinities. ${ }^{60}$

\section{The Use of Sacred Space in Enforcement of Morality}

Ezenagu observes that a particular space or a location is made sacred or holy with the presence of the divine beings believed to inhabit an arena. ${ }^{61}$ This fact is further explained by the fact that Africans associate such sacred spaces with

\footnotetext{
51 Mbiti, Introduction to African Religion, 124.

52 Ushe, "God, Divinities and Ancestors in African Traditional Religious thought," 164.

53 Ushe, "God, Divinities and Ancestors in African Traditional Religious thought," 164.

54 Joshua N. Kudadjie, "How morality was enforced in Ga-Adamgbe society" in Traditional Religion in West Africa, ed-Adegbola (Ibadan: Sefer books Ltd, 1998), 171.

55 Kudadjie, "How morality was enforced in Ga-Adamgbe society" 171.

${ }_{56}$ Ok Steven, Nwosu, "Morality in African Traditional Society" New Political Science, 26 no.2 (2004), 221.

7 Nwosu, "Morality in African Traditional Society," 221.

8 Kofi Agyekum, "Ntam reminiscential oath taboo in Akan," Cambridge University Press.33 no.3 (2004),321.

Agyekum, "Ntam reminiscential oath taboo in Akan," 321.

Agyekum, "Ntam reminiscential oath taboo in Akan," 328.

1 Ngozi Ezenagu, "Sacred Space: A Comparative study of Awka Traditional Shrines” Pharos Journal of Theology 97, (2016), 2.
} 
the gods. Hence it is at such sacred spaces that are believed to be the meeting point of the ancestors, the Supreme Being and the lesser gods and it is at such places that human beings communicate and commune with these beings who are noted to be the spiritual authorities. Such sacred spaces may include natural features like rivers, forests, rocks and mountains and artificial structures such as buildings which may be called temples. ${ }^{62}$ Ezenagu calls such a sacred space a shrine. The word shrine is derived from the Latin word scrinium which means a box or receptacle. According to Ezenagu, the function of this box or shrine is to incubate divinities. This means the shrine is used to keep divinities. In other words, it is at the shrine that divinities manifest their unseen presence to humans through their emblems. Ezenagu further reveals that the Yoruba believes that a shrine is a "local meeting place between the divinity and man."

According to Mbiti, outstanding mountains and hills are generally regarded as sacred and given religious meaning. ${ }^{63}$ The Bavenda and Shona people of Zimbabwe consider the Matopo hills or mountains to be a place of God's special manifestation. In Kenya, five mountains including the Mountain Kenya are also believed to be sacred and the dwelling places of God when he visits the earth and as such the Gikuyu people face the mountain when they pray. Such mountains are believed to give a concrete manifestation of God's presence and are also associated with spirits or divinities. Mbiti opines that the Yoruba people consider shrines as the "face" of a named divinity. For example, if a Ghanaian from Bonyere, in the Jomoro District in the Western Region visited the shrine of the River Tano (also called

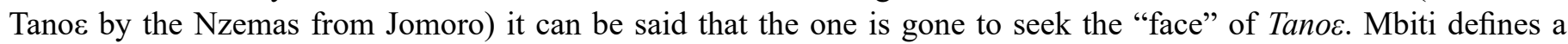
temple, which is also one of the sacred spaces, as a house or a building used for religious purposes and cared for by priests. An altar, however, is a particularly sacred spot where offerings and sacrifices are placed or made and they are mostly found in temples and shrines.

Mbiti is of the view that people go to the shrine to pray every morning before they speak to anyone which shows their mode of worship and dependence on God. ${ }^{64}$ It is an accepted fact, according to Mbiti, "that man should not, or cannot, approach God alone or directly, but that he must do so through the mediation of special persons or other beings". Given the above fact, one can go to pray to God through those special officials or priests at the shrine. Those who go to pray to God at the shrines also accompany their prayers with sacrifices.$^{65}$ African shrines can only be accessed by other people only in the presence or permission of the priests of the shrine.

In Africa, God (Onyame of the Akans or Olódùmarè of Yoruba) is conceived as holy and without any blemish and so the people conduct themselves with fear, respect and honour towards him. ${ }^{66}$ This is evident in the attitude displayed in presenting clean animals in the shrines or temples. ${ }^{67}$ Those officials or priests whose responsibility is to lead the people to perform the rituals and ceremonies must be men and women of high moral integrity devoid of committing murder, theft, adultery or anything evil in the community.

Ezenagu is also of the opinion that shrines serve as the "physical repository of morality" and as such, every shrine is engulfed with rules of conduct that are supposed to regulate human relations. ${ }^{68}$ Such rules are enforced by the gods such that the breach of any of them warrants severe punishment. Such rules are referred to as taboos. Some examples of such disapproved conducts are stealing, cheating, murder, incest, lying, covetousness and so on and those that are approved include kindness, hospitality, honesty, respectfulness, truthfulness and so on.

Ezenagu observes that worshippers of African deities visit shrines to get into contact with the object of worship and also have access to commune with the deity through the performance of various rituals like making sacrifices. ${ }^{69}$ African shrines are a source of the legal system in the sense that the African traditional laws which are unwritten are incorporated into the African traditional religion and it is at the shrine that those laws or rules are used as the basis of judgment. At the shrine, the ordained priest becomes the medium through which the gods dispense judgment using the traditional laws. This means the shrines become a source of law and order, peace and justice.

\section{METHODOLOGY}

This essay seeks to read the biblical text in the Traditional Religious context. Lobo points out three different methodologies in reading a text. ${ }^{70}$ The first focuses on the reader and his or her reading process (Reader's response), the second focuses rather on the text and the responsibility on the reader deriving all the meaning from the text (Literal criticism or New criticism) and the third focus is also on the reader and the authorial intent (Diachronic). ${ }^{71}$

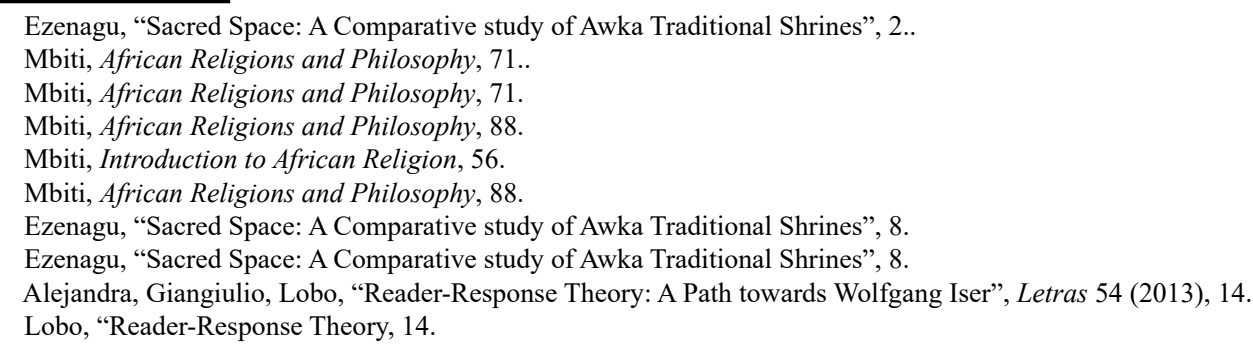


In the reader-response methodology, the reader does not passively read the text, but rather is actively engaged in making meaning out of the literature in an objective manner. ${ }^{72}$ In other words, there is an interaction between the text and the reader. In such a reading experience, meaning does not only depend on the text alone but also on the reader's background, viewpoint and so on and even the reason for reading. According to Nolte, texts are no longer viewed as monosemic, monolithic and stable structures that convey only one correct meaning as in New Criticism, but as aesthetic objects embedded in an ongoing process of reading, re-reading, reinterpretation and re-adaptation of the social values of people in different life situations. ${ }^{73}$

Therefore, texts no longer comprise one fixed meaning which is always uncovered when one reads a text but also found as a result of the ongoing process of reading, re-reading, reinterpretation and re-adaptation emanating from the social values of people in different life situations. Nolte again states that:

When readers read, they do so from specific vantage points which have been (in) formed at least by their upbringing, ethnicity, religious background, gender, academic history, cultural values, sexual orientation, psychological disposition, personality types and life stories..$^{74}$

Thus when one reads, the reading process passes through the upbringing, ethnic and religious backgrounds, and all these influences the way meaning is created from the text. From the above discussion on the methodology, readerresponse criticism has been used and the type of reading process in this methodology is an African traditional religious reading of the text. The researcher is an African and having analyzed the text, the concepts of a deity residing on a mountain and as such making the mountain sacred and the moral qualifications demanded from worshippers seem to be common in African Traditional Religion. The importance of the religious belief in African deities residing in mountains, the ritual and moral preparation is done by worshippers to approach such sacred places to seek solutions of problems and to offer sacrifices, make such texts more relevant when it is read with that African traditional religious background. In this methodology, the traditional religious beliefs in God, the Supreme Being and other supernatural beings and how they help to enforce morality is discussed in detailed. Having dealt with the above, such traditional beliefs are used as the context of interpreting the text under review.

\section{DISCUSSION}

Even though the whole text of Psalm 24 has been put up, what will be discussed is the second stanza (3-6) which is sung at the gate seeking admission into the temple or shrine. The second stanza, starting from versus 3 , is an enquiry which states as follows: "Who shall ascend the hill of the LORD? And who shall stand in his holy place"? As already stated, some Africans believe that the hills or mountains are the dwelling place of the Supreme Being when he visits the earth and as such making the mountains or hills a sacred place. This is in line with the Israelite belief which has the dwelling place of Yahweh to be Mountain Zion or Sinai. Given this same belief in God dwelling in mountains or hills, the African identifies with the fact that every sacred or holy place, believed to accommodate Yahweh or Onyame, can be referred to as a holy hill or the hill of Yahweh. Because of such beliefs, the worshipper who is seeking admission into the temple, which is also referred to as the hill of Yahweh, can enquire from the priest whether he or she qualifies to enter. The enquiry of the worshipper in the text (vrs.3), appeals to African traditional belief in the sense that shrines and temples cannot be entered by anybody except one is permitted by the priest in charge.

It is also believed among African worshippers that Onyame or Olódùmarè is holy and cannot be approached with any defilement, misconduct, or a breach of any taboo. For any worshipper to be able to enter into the hill of Yahweh or Onyame, he or she must be without blemish, or hidden misconduct and must be pure in the heart. In other words, for anyone to be granted access into the presence of God, the holy hill, he or she must observe rules of ritual purity which involves staying away from all prohibitions and not conceiving any evil both in the heart and mind. Due to the above belief, one must, in turn, inquire of the qualifications for entry, and then the priest has to respond with a list of qualifications. The enquiry is necessary because of the general belief that one must observe rules of ritual purity in order not to be stricken by Amadioha's thunder or Nyame aAkuma (God's axe). Due to this fore-knowledge, every worshipper tries to play safe by finding out the qualifications of entry so that if the worshipper falls short, he or she will have to make amends through prescribed sacrifices.

Four moral qualifications or entry requirements have been given for every worshipper seeking the face of Onyame to meet. They are clean hands and pure hearts, souls not defiled with falsehood and not swearing deceitfully. Clean hands and pure hearts are closely related attitudes with the hands representing human actions or conducts whiles hearts represent motives. According to Weanzana, clean hands mean "being innocent of any wrongdoing and not

\footnotetext{
72 Lobo, "Reader-Response Theory, 14.

73 Philip Nolte, "One text, many stories: The (ir) relevance of reader-response criticism for apocryphal literature in the Septuagint" HTS Teologiese Studies/ Theological Studies 68 no.1 (2012), 2-9.

74 Nolte, "The (ir) Relevance of Reader-response Criticism for Apocryphal Literature in the Septuagint", 9.
} 
harming others". ${ }^{75}$ It can be inferred from Weanzana's assertion concerning the use of "clean hands and pure hearts" that being innocent of wrongdoing may include both visible actions and motives, condition of thoughts and emotions which must be devoid of wrongdoing. ${ }^{76}$ Hence having clean hands and pure hearts consist of avoiding misconducts, having the right motives even when doing good, and not habouring any bitterness. In this case, hands and hearts signify visible actions and invisible motives.

Some African proverbs show the use of hands to signify one's conduct. For example, an Nzema (a tribe found in Ellembele and Jomoro districts in the Western Region of Ghana) proverb says that Se kakula ze ssanwo nrinzi a sne mgbanyinli di ale meaning "if a child or a neophyte knows how to wash his or her hands very well he or she can eat with the elderly people". This means if any child, youth or neophyte conducts himself or herself well and stays away from wrongdoing or leads a disciplined life, he or she finds favour with the old people and also has a close relationship with them. This shows that any worshipper leading a life devoid of any misconduct is believed to be approved by Onyame and as such qualified to be granted access into his shrine.

Another entry requirement into Onyame's shrine is one "who do not lift up their souls to what is false" [sic] or vain (which is interpreted as one whose thoughts are directed towards what is transitory, unreal and false). ${ }^{77}$ Attitudes that can constitute what is false, unreal and transitory may include all activities that are opposed to the nature of God or any habit that directs one's attention and passion away from God. ${ }^{78}$ Examples of such diversionary attitudes in Africa are materialism and hedonism. Anyone who wants to be granted access to Onyame's shrine must avoid anything, other than God, that is likely to occupy one's thoughts or anything that is given more priority than God.

The last entry requirement is one who does not swear deceitfully. In African belief, anyone who has taken an oath must be committed to telling the truth or being truthful to the promise made to be granted access into the shrine or temple. Since Onyame's eyes are capable of seeing every secret, anyone who wants to be admitted into the temple must ask for the pre-requisite criteria to fulfill in order not to attract the Nyame Akuma or Amadioha's thunder.

This implies that when a worshipper can fulfill all the entry requirements of keeping clean hands and pure hearts, souls not defiled with falsehood and not swearing deceitfully, he or she is allowed into the temple where Onyame or Olódùmarè resides. As the worshipper enters the temple to seek Onyame's face the priest, under the influence of the presence of Onyame, pronounces blessings upon the worshipper. Researchers believe that the priest in the temple or shrine does not just pronounce the blessings but performs rituals (like performing sacrifices) to invoke the presence of Onyame who is in the temple to release the blessing upon the worshipper.

\section{Implications of the Text for the Enforcement of Morality among African Christians}

According to Appiah-Sekyere, $71.1 \%$ of the Ghanaian population profess Christianity ${ }^{79}$ but the Corruption Perception Index survey in 2016 reveals that Ghana ranked second in West Africa, ninth in Africa and seventieth on the global scale ${ }^{80}$ This situation of corruption goes contrary to the moral purity being espoused in the text under review. Further, on the issue of corruption in Africa, Alhassan and Ugwuoke conclude in their research "that Religion is a significant determinant of the level of corruption in Africa. Also, Religiosity increases the level of corruption [sic] $\cdot{ }^{81}$ This conclusion is as a result of the high rate of spread of Christianity with a proportional increase in the level of corruption observed in Africa.

Agazue also reports of a worse scenario of misconduct where a prophet engaged in illicit sexual relations with young girls in the name of anointing their breasts and private parts with oil and called that act a "holy sex". ${ }^{82}$ Even though many people in Africa claim to be Christian, the above misconduct still persists among some Christians. The teachings concerning moral purity being espoused by this study must help to enforce morality among African Christians.

It is indicated in Acts 11:26, the Apostles of Jesus Christ and their followers were first called Christians because their lives emulated that of Christ their Master. In other words, Christians are people who followed the teachings and practised the exemplary life of Jesus Christ recorded in the New Testament. Furthermore, those followers of Christ not only followed his teachings but also worshipped him as their God, hence Jesus Christ could be referred to, in this context, as the Christian God. In this case, Christians who went to the temple, went to worship and to seek Jesus' face

\footnotetext{
75 Nupnaga Weanzana "Psalm 1-50" in African Bible Commentary (Nairobi: Word Alive Publishers, 2006) 636.

6 Weanzana "Psalm 1-50" in African Bible Commentary, 636.

James E. Smith, The wisdom literature and Psalms (Missouri: College Press Publishing Company, 1995).

8 Smith, The wisdom literature and Psalms.

79 Paul Appiah-Sekyere, "Environmental Care in Ghana: A Moral Duty for Ghanaian Christians" International Journal of Humanities Social Sciences and Education (IJHSSE) 3 no.11, November (2016), 55.

80 Joseph Gyanvi-Blay, "The Concept of the "Fear of God" in the wisdom literature: Implication for reformation of society and national development" E-Journal of Religious and Theological studies, 6 no.1, January (2020), 77.

81 Abdulkareem Alhassan \& Walter Okwudili Ugwuoke, "Religiosity, Institutions and Corruption in Africa" Journal of Economics and Sustainable Development, 9 no.18, (2018), 150.

82 Chima Agazue "'Spiritual Cleansing” through Private Parts: New Patterns of Sexual Exploitation of Female Church Members by their Revered "Prophets" in Nigeria" Conference Paper at The University Centre Blackpool and the Fylde College, July (2016), 3-4.
} 
as the people of Israel did for Yahweh in the Hebrew Bible.

Williams opines that the Israelite worship, which made use of the Psalter in general for various liturgical purposes and Psalm 24 in particular as a liturgy for entrance into the temple, is the foundation of Christianity founded by Jesus Christ. ${ }^{83}$ For the reason mentioned above, the moral purity both in the heart and conduct required by Yahweh from the worshippers entering the Israelite temple is also required from Christians by the Christian God to receive his blessings.

Even though the liturgy of the contemporary Christian Churches may not require any worshipper to stand at the entrance asking for qualifications to be met from their priests or pastors before entering the temples, observing the rules of ritual purity is still relevant. Not satisfying any entry requirement before entering a temple is the difference between Israelite worshipper and an African Christian worshipper. This might be due to what Christians are taught from Hebrew 4:15 which presents Christ as a high priest capable of helping the worshippers to deal with various moral weakness and as such allows everyone the entry.

African Christians have come from a background that sees moral purity as the most important spiritual commodity every worshipper must acquire to approach a deity hence it is required of every Christian to work on his or her morals to have a right standing with the Christian God. Given this, the moral qualifications of every African Christian are to stay away from various moral vices. To receive the blessing from the Christian God, it is also required of the African Christian worshipper to stay away from materialism or inordinate desire for money and property, covetousness and hedonism or pursuit of sensual pleasures that can direct one's focus away from God or deny God his first place. Even though everyone is granted access into a Christian shrine or temple, the blessings can only be received by the worshipper when he or she enters either with the attitude of purity and respect as demanded in the ancient Israelite case or use the liberty of entry to ask for forgiveness and cleansing prescribed to Christians in 1 John 1:9. ${ }^{84}$ Hence anyone who is not in good standing must enter the temple with a remorseful attitude to ask for forgiveness and cleansing, promising to remain pure, to receive the blessing.

It is known from the African traditional background, where priests are of high integrity and as such if someone is a pastor or man or woman of God, such moral integrity must not be questionable as it is being observed these days. Such high moral integrity is demanded from the people of God (Pastors, Bishops, Prophets) because such people, according to African belief, are the gatekeepers or custodians of the keys to the "physical repository of morality". If moral uprightness and high integrity should be likened to commodities that are in short supply everywhere, then the only person that must be asked for supplies is the gatekeeper who is the priest or the pastor. It is therefore incumbent on every pastor to show higher integrity to instill confidence in public and also be qualified to stand before the holy God who resides in the temple.

African Christians must appreciate the seriousness of the rules of ritual purity such as keeping clean hands and hearts, not lifting up one's soul to what is false, and not swearing deceitfully as found in the text under review. Unlike the ancient Israelite worshippers who had to observe such purity before entering the temple, the Christian of today is required to observe such purity every time. This is because Paul, an apostle and author of most New Testament books, espouses a strong teaching for Christians (1Cor 3:16; 6:19) saying that one's body is the temple of God and anyone who destroys it by uncleanliness and misconduct will be destroyed. In this teaching, the African Christian is expected to be in the temple always to observe all stipulated temple rituals with purity as long as he or she lives.

Apart from the fact that the African Christian must observe rules of ritual purity which befits a holy temple for God, every ritual including prayers, fasting, singing, giving offering or money to God in Church and all activities directed to God must be presented with clean hands and hearts. Thus before one performs any of the above or comes into contact with anything which has to do with God, one has to make amends by asking for forgiveness and cleansing if he or she does not meet the purity criteria. From such discussions, one can say that before one even holds the Bible, which is believed to be holy and is God's word to read, one must observe these rules of purity. This attitude prescribed ensures that every worshipper who enters the temple or encounters God anywhere qualifies for the blessings that are released.

From the study, it has been established that receiving a blessing from God is by observing rules of ritual purity and not by giving to the church or a man of God. Pastors have so much emphasized giving as the sure way of receiving from God but the text here has rather emphasized having clean hands and hearts, making sure that the souls are not lifted up to what is false, and not swear deceitfully which constitute rules of ritual purity. Even though giving is important, what is more important for God to accept an offering or gift is by Christians first observing these rules of ritual purity.

\footnotetext{
83 Donald, Williams, "The Israelite cult and Christian worship" in The use of the Old Testament in the new and other essays studies in honor of William Franklin Stinespring. (Durham: Duke University press, 1972) 110.

84 "If we confess our sins, he who is faithful and just will forgive us our sins and cleanse us from all unrighteousness".
} 


\section{CONCLUSIONS}

Ancient Israelites and Africans jointly believe in Yahweh and Onyame respectively as the monotheistic God who has been in a covenantal relationship with humanity. This God is also known to dwell on mountains making every sacred place to be called a holy hill or the hill of Yahweh. The priest or pastor who leads people to perform every ritual in the shrine must be one without blemish and defilement since he or she is the custodian of the repository of morality. In this case, those patronizing the shrine must follow the priest's example of observing ritual purity to qualify to enter the sacred place. If there is any defilement one has to make amends through sacrifice before entry.

In the Israelite cult of Yahweh, the worshippers ask for entry requirements from the priest at the gate and the list of qualifications of ritual or moral purity are having clean hands and pure hearts not lifting up the souls to what is false and not swearing deceitfully. Such moral qualities are the rules which must be observed before one enters the shrine to engage in any form of ritual such as making sacrifices, prayer, singing or anything.

Unlike the ancient Israelite cult and African Traditional beliefs, the Christian has to enter the temple with a remorseful heart to make any amends by asking the Christian God for forgiveness. Another difference is that emphasis on moral purity becomes pronounced when one must visit the shrine in the case of ancient Israelite and African traditionalist as seen in the text but with the Christian, one is always expected in the temple since the Christian believes that his or her body is the temple of God and as such must be kept pure every time to keep the presence of God.

There is a general belief among Christians that blessings can only be obtained through giving but this study reveals that it is by observing moral or ritual purity that attracts the blessings and as such pastors need to emphasize that in their preaching. From this research, African Christians are expected to observe rules of moral purity since the background emphasizes that and as such when one becomes a Christian the demand for him or her to observe moral purity becomes higher.

\section{ABOUT AUTHORS}

Joseph Gyanvi-Blay is a lecturer in the Faculty of Humanities, Department of Theology, Christian Service University College, Kumasi-Ghana. He holds both M.A and MPhil in Religion and Human Values at the University of Cape-Coast, Ghana.

Emmanuel Twumasi-Ankrah is a lecturer in the Faculty of Humanities, Department of Theology, Christian Service University College, Kumasi-Ghana. He is a Ph.D. Candidate in the Department of Religious Studies, Kwame Nkrumah University of Science and Technology, Kumasi - Ghana. His area of specialization is Old Testament Theology and Ethics and Biblical Hebrew.

\section{BIBLIOGRAPHY}

Agazue, Chima "'Spiritual Cleansing" through Private Parts: New Patterns of Sexual Exploitation of Female Church Members by their Revered "Prophets" in Nigeria" Conference Paper at The University Centre Blackpool and the Fylde College, July 2016, 3-4. https://doi.org/10.23860/dignity.2016.01.01.10

Agyekum, Kofi. “Ntam reminiscential Oath Taboo in Akan." Cambridge University Press.33, no.3 (2004): 321-328. https://doi.org/10.1017/s0047404504043015

Alhassan, Abdulkareem \& Ugwuoke, Walter Okwudili, "Religiosity, Institutions and Corruption in Africa" Journal of Economics and Sustainable Development, 9 no.18 (2018), 150.

Appiah-Sekyere, Paul "Environmental Care in Ghana: A Moral Duty for Ghanaian Christians," International Journal of Humanities Social Sciences and Education (IJHSSE) 3 no.11 (2016), 55.

https://doi.org/10.20431/2349-0381.0311008

Dahood, Mitchell, Psalm 1-50: Introduction, translation and Notes. London: Yale University Press, 2003.

Day, J. Psalms. New York: T\&T Clark International, 1999.

Erickson, Millard, The Concise Dictionary of Christian Theology. Wheaton, Illinois: Crossway Books, Good News Publishers, 2001.

Ezenagu, Ngozi. "Sacred Space: A Comparative study of Awka Traditional Shrines". Pharos Journal of Theology, 97 (2016): 2-9.

Gunkel, Herman. The Psalms: A form-critical Introduction. trans. Thomas M. Honer, Philadelphia: Fortress Press, 1969, 11-39.

Gyanvi-Blay, Joseph. "The Concept of the "Fear of God" in the Wisdom Literature: Implication for Reformation of 
Society and National Development." E-Journal of Religious and Theological Studies 6, no. 1 (2020): 69-79. https://doi.org/10.32051/01202008.

Hayes, John. "The songs of Israel: Psalm and Lamentation" in The Hebrew Bible today: An Introduction to Critical Issues.Louisville, Kentucky: Westminster John Knox Press, eds Steven L. Mckenzie \& M. Patrick Graham, 1998, 157-161.

Idowu, Bolaji E. Olódùmarè: God in Yoruba belief. London: Longmans Green and Co. Ltd, 1966, 31-108.

Ikechukwu, Nwafor Matthew. "The living-dead (ancestors) among the Igbo-African people: An interpretation of Catholic sainthood" International Journal of Sociology and Anthropology(2017). https://doi.org/10.5897/ijsa2017.0719

Ikenga-Metuh,Emefie. "Ritual Dirt and Purification Rites among the Igbo," Journal of Religion in Africa, 15 no.1 (1985): 3-24. https://doi.org/10.1163/157006685×00020

Kselman, John \& Barré, Michael. "Psalms" in The New Jerome Biblical Commentary. Bangalore: Theological Publications, 1992, 525-530.

Kudadjie, J.N. "How morality was enforced in Ga-Adamgbe society". in Traditional Religion in West Africa, ed Adegbola, Ibadan: Sefer books Ltd, 1998, 170-176.

Lobo Giangiulio Alejandra. "Reader-Response Theory: A Path towards Wolfgang Iser," Letras 54, 2013.

Mbiti, John S. African Religions and Philosophy. Garden City, New York: Anchor Books Doubleday \& Company, Inc., 1970, 71-98. . Introduction to African Religion. Nairobi: Heinemann Educational Publisher, 1991, 56-124.

Mondriaan, M. E. The Rise of Yahwism: role of marginalized groups. Unpublished doctoral thesis, Department of the Old Testament Studies. The University of Pretoria, 2010, 228-311.

Mowinckel, Sigmund. The Psalms in Israel's Worship. Nashville: Abingdon Press, 1967, 2-219.

Nolte, Philip. "One text, many stories: The (ir) Relevance of Reader-response Criticism for Apocryphal Literature in the Septuagint.” HTS Teologiese Studies/Theological Studies 68 no.1 (2012): 2-9. https://doi.org/10.4102/hts.v68i1.1092

Nwosu, Ok. Steven. "Morality in African Traditional Society," New Political Science, 26 no.2, 2004.

Oesterley, W. O. E. \& Robinson, T.H. Hebrew religion: Its origin and development. London: S.P.C.K., 1961.

Sabourin, Leopold. The Psalms. New York: Society of St Paul, 1974, 3-405.

Smith, James E. The wisdom literature and Psalms. Missouri: College Press Publishing Company, 1995.

Ushe Mike Ushe. "God, Divinities and Ancestors in African Traditional Religious thought." Igwebuike: An African Journal of Arts and Humanities, 3 no.4 (2017): 155-165.

Weanzana, Nupnaga. "Psalm 1-50” in African Bible Commentary. Nairobi: Word Alive Publishers, 2006.

Williams, Donald. The Israelite Cult and Christian Worship. "The use of the Old Testament in the new and other essays studies in honor of William Franklin Stinespring.” Durham: Duke University Press, 1972, 110-124. 